\section{OPEN ACCESS}

Edited by:

Sotiria D. Mastroyianni,

Panagiotis \& Aglaia Kyriakou Children's Hospital, Greece

Reviewed by:

Mitchell Schertz,

Technion Israel Institute of

Technology, Israel

Simona Fiori,

Fondazione Stella Maris (IRCCS), Italy

*Correspondence:

Heng Liu

zmcliuh@163.com

Jian Yang

yj1118@mail.xjtu.edu.cn

†These authors have contributed equally to this work

Specialty section:

This article was submitted to

Pediatric Neurology,

a section of the journal

Frontiers in Neurology

Received: 16 March 2020

Accepted: 23 July 2020

Published: 08 September 2020

Citation:

Wu F, Wang X, Li X, Jiang H, Huang T,

Liu C, Wang $M$, Zhai Z, Zhang $X$,

Zhang J, Liu H and Yang J (2020) The

Most Cited Original Articles in Brain

Imaging of Children With Cerebral

Palsy: A Bibliometric Analysis

Between 1984 and 2019.

Front. Neurol. 11:955.

doi: 10.3389/fneur.2020.00955

\title{
The Most Cited Original Articles in Brain Imaging of Children With Cerebral Palsy: A Bibliometric Analysis Between 1984 and 2019
}

\begin{abstract}
Fan $\mathrm{Wu}^{1,2+}$, Xiaoyu Wang ${ }^{1+}$, Xianjun $\mathrm{Li}^{1}$, Haoxiang Jiang ${ }^{1,3}$, Tingting Huang ${ }^{1,4}$, Congcong Liu ${ }^{1}$, Miaomiao Wang ${ }^{1}$, Zhonghui Zhai ${ }^{5}$, Xiaoman Zhang ${ }^{5}$, Jingjing Zhang ${ }^{6}$, Heng Liu ${ }^{1,6 *}$ and Jian Yang ${ }^{1,3 *}$
\end{abstract}

\begin{abstract}
${ }^{1}$ Department of Radiology, The First Affiliated Hospital of Xi'an Jiaotong University, Xi'an, China, ${ }^{2}$ Department of Radiology, Guangzhou Women and Children's Medical Center, Affiliated Guangzhou Medical University, Guangzhou, China, ${ }^{3}$ The Key Laboratory of Biomedical Information Engineering, Ministry of Education, Department of Biomedical Engineering, School of Life Science and Technology, Xi'an Jiaotong University, Xi'an, China, ${ }^{4}$ Department of Radiology, The First Affiliated Hospital of Henan University of TCM, Zhengzhou, China, ${ }^{5}$ Xi'an Jiaotong University Library, Xi'an, China, ${ }^{6}$ Department of Radiology, Medical Imaging Center of Guizhou Province, Affiliated Hospital of Zunyi Medical University, Zunyi, China
\end{abstract}

Objective: Brain imaging is important in diagnosing children with cerebral palsy (CP) and in identifying its etiology. To provide study navigation in this field, a bibliometric analysis was conducted by analyzing the most highly cited articles.

Methods: The Web of Science All Databases were used for literature search in this study. All original articles on imaging in children with CP were searched. Two reviewers screened the search results independently and eliminated articles based on exclusion criteria such as participants over 20 years old, topics referring to images outside of the brain, or trauma. According to descending order of yearly citation counts, the top $25 \%$ of all included articles were considered as highly cited articles. Information such as yearly citations, research purposes, imaging modalities, CP types, and study designs were recorded and analyzed.

Results: A total of 50 highly cited articles ranked by yearly citations (from 23.85 to 3.33 , 1991-2018) were included in this study. Considering different research purposes, these studies were classified into three categories: diagnosis studies $(n=25$; 1991-2017, median: 2011), mechanism studies ( $n=15$; 1999-2018; median: 2014), and prognosis and therapeutic effect studies ( $n=10$; 2008-2017; median: 2014.5). First, for diagnosis studies, 22 studies used single modality and three used multi-modalities; the majority of these studies focused on diagnostic value evaluation $(n=10)$ and image performance ( $n=12)$ of a single type of CP $(n=15)$ by using descriptive $(n=14)$ or cross-sectional approaches $(n=10)$. Second, for mechanism studies, the ratio between single and multi-modality was 8:7; most of these studies concentrated on a single subtype of spastic CP (hemiplegia $=10$, quadriplegia $=2$ ) with a cross-sectional study design $(n=10)$. Third, regarding the prognosis and therapeutic effect studies, the single vs. multi-modality ratio was 5:5, and these studies were dedicated to the efficiency of constraint-induced movement therapy in children with hemiplegia; paired design trials $(n=6)$ and randomized controlled trials $(n=2)$ were used more frequently. 
Conclusion: Studies using multi-modality and high-level evidence-based design to provide information regarding mechanism, prognosis, and therapeutic efficacy may be the potential future research direction in the field of CP research.

Keywords: bibliometric analysis, brain imaging, cerebral palsy, children, citation analysis, neuroimaging

\section{INTRODUCTION}

Cerebral palsy (CP) is a group of permanent movement disorders attributed to non-progressive disturbances occurring during fetal or infant brain development (1). The prevalence of CP for all live birth ranges from 2 to 3 per 1,000 live births (2). However, this prevalence varies for different regions or countries depending on income level, and a higher prevalence has also been reported in infancy compared to all live births $(1,2)$. Brain sonography, a diagnostic imaging tool, was the first technique used to detect brain lesions in CP patients at 1984 (3). Moreover, in 2004, the American Academy of Neurology and the Child Neurology Society jointly published a practice parameter recommending neuroimaging examination as a necessary evaluation procedure for CP children with uncertain etiology (4). In recent years, the field of neuroimaging has made significant progress in early and accurate CP diagnosis (5), mechanism of action, prediction of therapy effect, and prognosis (functionality) (68). Brain imaging has become one of the main focuses of CP research, with numerous articles published on this topic. In the current imaging evaluation era of $\mathrm{CP}$, a substantial volume of literature comprising studies on varying topics and designs are available to neurologists, pediatric neurologists, pediatricians, and radiologists. However, due to the lack of quantitative research providing an overview of brain imaging studies in CP patients (9), it is challenging for students, residents, and researchers new to the field to identify the most important study areas and future direction. Therefore, distilling the newest and emerging research in this field through citation counts can help create an evidence-based approach to guide future study.

Bibliometric analysis was previously used to quantitatively survey knowledge development in imaging and neuroimaging fields (10). Compared to meta-analysis and systemic review, which both focus on specific questions such as study population, methods, and findings, the bibliometric analysis provides an overview of the study field from a different angle, by using bibliographic material such as yearly citations, authors' information, and impact factor (IF) of the publishing journals (11). These three types of studies have distinct focuses and provide information that can complement each other in a given field. According to our research, no previous bibliometric analysis has been done on brain imaging of children with CP. Thus, we have selected the bibliometric analysis method to quantitatively evaluate the knowledge structure and development of pediatric CP imaging, to highlight emerging themes and future study trends in this field.

This study aimed to perform a citation analysis of the most cited papers on brain imaging in children with CP and analyzed each paper individually according to imaging modality, year of publication, yearly citations, research purposes, study designs, country of origin of the first author, and IF of the journal.

\section{MATERIALS AND METHODS}

As our study was a retrospective bibliometric analysis of publicly available study literature, it was exempt from institutional review board approval.

\section{Literature Search}

To identify the most highly cited articles, we conducted a systematic literature search on CP brain imaging for children articles, published from November 4, 2019. We used the Web of Science All Databases (Clarivate Analytics, Philadelphia, United States), which included the MEDLINE database; the results were limited to the English language with no publication year limit. The searching topics were listed:

"cerebral palsy" or "brain paralysis" or "monoplegia" or "unilateral paralysis" or "diplegia" or "quadriplegia" or "tetraplegia" or "hemiplegia" or "hemiparesis" or "static encephalopathy"

and

"diffusion tensor imaging" or "DTI" or "diffusion kurtosis imaging" or "DKI" "neuroradiology" or "neuroimaging" or "brain imaging" or "brain CT" or "head CT" or "computed tomography" or "MRI" or "MR imaging" or "magnetic resonance imaging" or "DWI" or "diffusion-weighted imaging" or "MR perfusion" or "magnetic resonance perfusion" or "SPECT" or "PET" or "sonography" or "ultrasound" or "doppler" or "network" or "connect*" and "infant*” or "child*" or "pediatric" or "toddler*" or "bab*" or "trottie" or "kid*" or "neonate*" or "newborn*" or "adolescent*" or "teenager" or "juvenile*” or "teen*".

All original articles on imaging in children with CP were included. Exclusion criteria were articles concerning participants over 20 years old, or topics referring to images of the spinal cord, musculoskeletal, urinary systems, vascular ultrasounds, ultrasound-guided therapy, hemi-convulsion-hemiplegia syndromes, or trauma.

\section{Screening of Highly Cited Original Articles}

Two reviewers (Fan $\mathrm{Wu}$ and Jingjing Zhang) screened the search results independently. Full-text articles were retrieved and screened according to the inclusion and exclusion criteria. In case of doubt, a third reviewer (Heng Liu) participated in the screening. Two reviewers independently extracted data and stored them electronically in Microsoft Excel 2016. The results were downloaded to a local database. From a list of articles in descending order of yearly citations (total citation count divided 
by the year difference between publication year and 2019), the top $25 \%$ were considered the most highly cited (12).

\section{Data Analysis}

For the most highly cited articles in the final analysis, the following information was collected and listed: yearly citations, total citations, research purposes, CP types, study designs, imaging modalities, subjects age, modality of study acquisition, country of the first author, publication journal, and journal IF. For descriptive analysis of the CP types, imaging modalities, study designs, author or publication information, and number and proportion of articles were listed.

\section{RESULTS}

Among 6,137 published articles, 202 on brain imaging in children with $\mathrm{CP}$ were identified based on our inclusion and exclusion criteria. A total of 50 articles were defined as the most highly cited articles according to the ranking number of yearly citations.

\section{Top 50 Highly Cited Original Articles}

Table 1 lists the bibliometric materials of the top 50 highly cited original articles, regarding particulars such as citation counts, imaging modalities, and author and publication information. The yearly citation counts ranged from 23.85 to 3.33 per year (median: 6/year), and the total citation counts were between 310 and 7 (median: 45.5 times). According to different research purposes, the articles were classified into three categories: $\mathrm{CP}$ diagnosis studies (25 articles, 50\%), CP mechanism studies (15 articles, $30 \%$ ), and CP prognosis and therapeutic effect studies (10 articles, $20 \%)$. Based on the above classification, we explored the imaging modalities, CP types, impaired functions, study designs, country of origin of the first author, and journal's IF of these articles.

\section{Application of Imaging Modalities in the Top 50 Highly Cited Articles}

Figure 1A shows the yearly publication count distribution of the top 50 highly cited original articles that applied single or multiple modalities. The article publication numbers showed an increasing trend over time. Thirty-five studies used single modality (CP diagnosis: $n=22$; $\mathrm{CP}$ mechanism: $n=8$; $\mathrm{CP}$ prognosis and therapeutic effect: $n=5$ ), whereas 15 studies were multi-modality studies with a growth trend in the past 10 years (CP diagnosis: $n=3$; $\mathrm{CP}$ mechanism: $n=7$; $\mathrm{CP}$ prognosis and therapeutic effect: $n=5$ ). Among multi-modality studies, multiple imaging modalities were applied in eight studies. Specifically, seven studies used two imaging modalities [structural magnetic resonance imaging (sMRI) (1991) and transcranial ultrasound (TCS) $=1,1993$; sMRI and diffusion tensor imaging $(\mathrm{DTI})=4,2007-2015$; DTI and functional MRI (fMRI) $=1,2015$; sMRI and fMRI $=1,2016]$, and one study used three imaging modalities [DTI, sMRI, and diffusion-weighted imaging (DWI) $=1,2017]$. Seven studies combined an imaging modality with an electrophysiological modality [magnetoencephalography (MEG) $=2,2014$ and 2018; transcranial magnetic stimulation (TMS) $=5,2010-2017]$. Thus, combining an imaging modality with an electrophysiological modality could be a possible study direction for brain imaging studies in children with $\mathrm{CP}$.

Figure 1B shows the yearly article counts of each image modality used in the top 50 highly cited original articles according to different research purposes. First, sMRI (1991) and TCS (1992) were used the earliest in CP diagnosis studies ( $n$ $=25$ ), and DTI (29 times) and sMRI (29 times) were used the most. Second, computed tomography (CT) was applied as a complementary method to sMRI in six CP diagnosis studies to help identify imaging performance. Third, multi-modalities were applied more frequently in $\mathrm{CP}$ mechanism studies since 2011 (8/15 studies), especially DTI combined with other MR technologies, TMS and MEG. Last, the prognosis $(n=1)$ and therapeutic affect studies $(n=9)$ first appeared in 2008, and the utilization of multi-modality in these types of studies has increased remarkably from $2013(n=5)$.

\section{CP Types, Impaired Functions, and Study Designs of the Top $\mathbf{5 0}$ Highly Cited Articles}

Table 2 lists the article counts of CP types, impaired functions, and study designs of the top 50 highly cited articles, as well as their publication years and distribution among different research purposes. CP diagnosis studies were further classified into diagnostic value of imaging methods (1993-2014, median: 2007.5), brain image performance (1991-2012, median: 2008.5), imaging classification systems, and imaging post-processing applications (2011-2017, median: 2014). The CP mechanism studies (1999-2018, median: 2014) have been explored from the 1990 's. The prognosis and therapeutic effect studies involved four distinct types of treatment (2008-2017, median: 2014.5) presenting with a number of increases in the past 10 years.

\section{CP Types and Impaired Functions}

Regarding the $\mathrm{CP}$ types, articles mainly focused on single $\mathrm{CP}$ type study, specifically spastic CP (SCP) (37/50, 74\%) (Table 2). The single subtype studies constituted of approximately $78 \%(29 / 37)$ spastic CP studies, and hemiplegia constituted of 79\% (23/29) single subtype studies. Limited to early imaging technological development, most studies concentrated on the diagnostic value of specific imaging methods in CP (8/10) or identified unique image performances and feature classification in different $\mathrm{CP}$ types or subtypes (13/15). The majority of CP mechanism studies focused on single subtype SCP, particularly hemiplegia (10/15) and quadriplegia $(2 / 15)$. The prognosis and therapeutic effect studies concentrated closely on constraint-induced movement therapy (CIMT) (5/10), bimanual intensive rehabilitation $(1 / 10)$, and hand function prediction $(1 / 10)$ of children with hemiplegia. Moreover, an article on botulinum injection studied patients with quadriplegia $(1 / 10)$, and the autologous cord blood infusion studies $(2 / 10)$ were also performed in children with CP but did not mention any particular $\mathrm{CP}$ subtype.

Concerning impaired functions, 32 out of 50 articles included impaired function in their studies (64\%). Hand or upper limb function $(19 / 50,38 \%)$ and sensorimotor pathway function $(13 / 50,26 \%)$ received the most attention from researchers. In addition, four articles described the relationship between brain structure changes and cognitive functions (including speech 
TABLE 1 | The top 50 highly cited brain imaging articles in children with cerebral palsy ranked by yearly average citation.

\begin{tabular}{|c|c|c|c|c|c|c|c|c|c|c|c|c|}
\hline Rank & Article name & Main author & Journal & IF (2018) & $\begin{array}{l}\text { Brain } \\
\text { imaging } \\
\text { modality }\end{array}$ & $\begin{array}{l}\text { Single } \\
\text { modality; } \\
\text { multiple } \\
\text { modality }\end{array}$ & Age & $\begin{array}{l}\text { Modality of } \\
\text { study } \\
\text { acquisition }\end{array}$ & $\begin{array}{l}\text { Publication } \\
\text { Year }\end{array}$ & $\begin{array}{l}\text { No. of yearly } \\
\text { citations }\end{array}$ & $\begin{array}{l}\text { No. of total } \\
\text { citations }\end{array}$ & $\begin{array}{l}\text { Rank of total } \\
\text { citations }\end{array}$ \\
\hline 1 & $\begin{array}{l}\text { Clinical and MRI correlates of cerebral } \\
\text { palsy - the European cerebral palsy study }\end{array}$ & Bax, M. & JAMA & 51.27 & sMRI & Single & $\begin{array}{l}0.08-7.25 \\
\text { years }\end{array}$ & - & 2006 & 23.85 & 310 & 1 \\
\hline 2 & $\begin{array}{l}\text { Sensory and motor deficits in children with } \\
\text { cerebral palsy born preterm correlate with } \\
\text { diffusion tensor imaging abnormalities in } \\
\text { thalamocortical pathways }\end{array}$ & Hoon, A. H. Jr. & $\begin{array}{l}\text { Developmental } \\
\text { Medicine and } \\
\text { Child Neurology }\end{array}$ & 3.53 & DTI & Single & $\begin{array}{l}1.25-15 \\
\text { years }\end{array}$ & Sedation & 2009 & 17.4 & 174 & 3 \\
\hline 3 & $\begin{array}{l}\text { Quantitative diffusion tensor imaging in } \\
\text { cerebral palsy due to periventricular white } \\
\text { matter injury }\end{array}$ & Thomas, B. & Brain & 11.81 & DTI & Single & $12-16$ years & Awake & 2005 & 13.21 & 185 & 2 \\
\hline 4 & $\begin{array}{l}\text { Effect of autologous cord blood infusion on } \\
\text { motor function and brain connectivity in } \\
\text { young children with cerebral palsy: a } \\
\text { randomized, placebo-controlled trial }\end{array}$ & Sun, J. M. & $\begin{array}{l}\text { STEM CELLS } \\
\text { Translational } \\
\text { Medicine }\end{array}$ & 5.96 & $\begin{array}{l}\text { DTI, sMRI, } \\
\text { and DWI }\end{array}$ & Multiple & $1-6$ years & - & 2017 & 12 & 24 & 37 \\
\hline 5 & $\begin{array}{l}\text { Corticospinal tract diffusion properties and } \\
\text { robotic visually guided reaching in children } \\
\text { with hemiparetic cerebral palsy }\end{array}$ & Kuczynski, A. M. & $\begin{array}{l}\text { Human Brain } \\
\text { Mapping }\end{array}$ & 4.55 & DTI & Single & $6-19$ years & - & 2018 & 11 & 11 & 48 \\
\hline 6 & $\begin{array}{l}\text { Hand function in relation to brain lesions } \\
\text { and corticomotor-projection pattern in } \\
\text { children with unilateral cerebral palsy }\end{array}$ & Holmstrom, L. & $\begin{array}{l}\text { Developmental } \\
\text { Medicine and } \\
\text { Child Neurology }\end{array}$ & 3.53 & $\begin{array}{l}\text { sMRI and } \\
\text { TMS }\end{array}$ & Multiple & $7-16$ years & - & 2010 & 10.22 & 92 & 10 \\
\hline 7 & $\begin{array}{l}\text { Function and neuroimaging in cerebral } \\
\text { palsy: a population-based study }\end{array}$ & Himmelmann, K. & $\begin{array}{l}\text { Developmental } \\
\text { Medicine and } \\
\text { Child Neurology }\end{array}$ & 3.53 & sMRI or CT & Single & $4-8$ years & - & 2011 & 9.5 & 76 & 15 \\
\hline 7 & $\begin{array}{l}\text { MRI classification system (MRICS) for } \\
\text { children with cerebral palsy: development, } \\
\text { reliability, and recommendations }\end{array}$ & Himmelmann, K. & $\begin{array}{l}\text { Developmental } \\
\text { Medicine and } \\
\text { Child Neurology }\end{array}$ & 3.53 & sMRI & Single & - & - & 2017 & 9.5 & 19 & 43 \\
\hline 9 & $\begin{array}{l}\text { Quantitative diffusion tensor tractography } \\
\text { of the motor and sensory tract in children } \\
\text { with cerebral palsy }\end{array}$ & Yoshida, S. & $\begin{array}{l}\text { Developmental } \\
\text { Medicine and } \\
\text { Child Neurology }\end{array}$ & 3.53 & DTI & Single & $0.33-9$ years & $\begin{array}{l}\text { Partial } \\
\text { sedation }\end{array}$ & 2010 & 8.78 & 79 & 14 \\
\hline 10 & $\begin{array}{l}\text { Diffusion tensor imaging in children with } \\
\text { periventricular leukomalacia: variability of } \\
\text { injuries to white matter tracts }\end{array}$ & Nagae, L. M. & $\begin{array}{l}\text { American Journal } \\
\text { of Neuroradiology }\end{array}$ & 3.26 & DTI & Single & $\begin{array}{l}1.33-13.25 \\
\text { years }\end{array}$ & Sedation & 2007 & 8.75 & 105 & 8 \\
\hline 11 & $\begin{array}{l}\text { Cerebral palsy in a term population: risk } \\
\text { factors and neuroimaging findings }\end{array}$ & Wu, Y. W. & Pediatrics & 5.4 & sMRI or CT & Single & - & - & 2006 & 8.62 & 112 & 5 \\
\hline 12 & $\begin{array}{l}\text { Diffusion tensor imaging of periventricular } \\
\text { leukomalacia shows affected sensory } \\
\text { cortex white matter pathways }\end{array}$ & Hoon, A. H. & Neurology & 8.69 & DTI & Single & $4-8$ years & - & 2002 & 8.47 & 144 & 4 \\
\hline
\end{tabular}




Journal

\section{IF (2018) Brain}

Brain
modality

3 Structural neuroplastic change after constraint-induced movement therapy in children with cerebral palsy.

14 Is outcome of constraint-induced movement therapy in unilateral cerebral palsy dependent on corticomotor

15 Cortical somatosensory reorganization in children with spastic cerebral palsy: a multimodal neuroimaging study

16 Assessment of the structural brain network Pannek, K. reveals altered connectivity in children with unilateral cerebral palsy due to periventricular white matter lesions.

16 Magnetic resonance imaging findings in a Robinson, M. N. Developmental population-based cohort of children with cerebral palsy

18 MRI structural connectivity, disruption of primary sensorimotor pathways, and hand function in cerebral palsy.

19 Population-based study of neuroimaging Towsley, $\mathrm{K}$. findings in children with cerebral palsy

20 Reorganization of the somatosensory cortex in hemiplegic cerebral palsy associated with impaired sensory tracts.

21 Speech problems affect more than one in two children with cerebral palsy: Swedish population-based study

22 Quantitative analysis of brain pathology based on MRI and brain atlasesapplications for cerebral palsy

23 Brain structural connectivity increases concurrent with functional improvement: evidence from diffusion tensor MRI in

24 Sensory tractography and robot-quantified Kuczynski, A. M. Human Brain proprioception in hemiparetic children with

$5.4 \quad \mathrm{MR}$

TMS

and MEG

3.53 sMR and DTI

3.94 DTI

4.55 DTI projection pattern and brain lesion characteristics? children with cerebral palsy during therapy
Mapping

Medicine and

Child Neurology

Brain Connectivity

European journal of Pediatric

Neurology

Papadelis, C. Neurolmage-

Clinical

Nordberg, A. Acta Paediatrica

Faria, A. V. Neuroimage

Englander, Z. A. Neurolmage-

Clinical

\section{Single Age}

modality;

modality;

modality

Single

$2.08-7$

Moda

Publication No. of yearly No. of total Rank of total

tudy

acquisition

Single

years

3.53 SMRI and Multiple 8-16 years -

(a)

DTI, fMRI, Multiple

4.75-17 Awake

years

(1)

2014

Single

5-7 years -

2009

7.4

2011

7.38

years

$0-5.50$ years -

2011

7.25

20

3.94 MEG, sMRI, Multiple 6-17 years -

2.27 SMRI or CT Single

2018

7

7

Single

4-13 years Sedation

2011

6.5

52

Single

6.25

Single

2017

6

22

(n)

(6) proprioception in
perinatal stroke 
Main author Journal

IF (2018) Brain

Brain

Single

modality

Age

ge

Mo

Modality

acquisition

modality

24 Using diffusion tensor imaging to identify $\mathrm{KuO}, \mathrm{H}, \mathrm{C}$.

Developmental

Medicine and

corticospinal tract projection patterns in

children with unilateral spastic cerebral

palsy.

24 Validity of semi-quantitative scale for brain MRI in unilateral cerebral palsy due to periventricular white matter lesions: relationship with hand sensorimotor

function and structural connectivity

27 Neuroradiology can predict the development of hand function in children with unilateral cerebral palsy

28 Gastrointestinal manifestations in children with cerebral palsy.

29 Capturing neuroplastic changes after bimanual intensive rehabilitation in children with unilateral spastic cerebral palsy: a combined DTI, TMS and fMRI pilot study

30 DTI-based three-dimensional

tractography detects differences in the pyramidal tracts of infants and children with congenital hemiparesis

31 Diffusion tensor imaging study of the response to constraint-induced

movement therapy of children with

hemiparetic cerebral palsy and adults with

chronic stroke

31 Reliability of a novel, semi-quantitative scale for classification of structural brain magnetic resonance imaging in children with cerebral palsy

33 Correlation of quantitative sensorimotor tractography with clinical grade of cerebral palsy

34 Diffusion tensor MR imaging tractography of the pyramidal tracts correlates with clinical motor function in children with congenital hemiparesis

35 Neuroplastic sensorimotor resting state network reorganization in children with hemiplegic cerebral palsy treated with constraint-induced movement therapy.

- Neurolmage-

Clinica

Holmefur, M.

Neurorehabilitation and Neural Repair

Del, G. E.

Brain \&

Development

Bleyenheuft, Y. Research in

Developmental

Disabilities

$\begin{array}{ll}\text { Glenn, O. A. } & \text { Journal of } \\ & \text { Magnetic } \\ & \text { Resonance } \\ & \text { Imaging }\end{array}$

Rickards, T- Archives of

Physical Medicin

and Rehabilitation

Fiori, S.

Developmenta

Medicine and

Child Neurology

Trivedi, R.

Neuroradiology

Glenn, O. A.

American journal

of Neuroradiology

Manning, K. Y. Journal of Child

Neurology
DTI and TMS Multiple

$6.08-17.08-$

years

$11.40 \pm 3.10-$

years

3.76 SMRI or CT Single

1.76 SMRI or CT Single

DTI, fMR

and TMS

Multiple

$$
\text { years }
$$

6-9 years

75-9 years -

0.83-3.67-

years

2.10-7.60 Sedation

years

$3.53 \quad$ SMRI Single

4-16.92

years

2.5

DTI

Single

3-12 years -

$0.54-17.44$

years

MRI

Year

citations

No. of tota

citations

ank of tota

46

2017

(1)

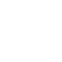

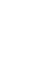

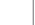




\begin{tabular}{|c|c|c|c|c|c|c|c|c|c|c|c|c|}
\hline Rank & Article name & Main author & Journal & IF (2018) & $\begin{array}{l}\text { Brain } \\
\text { imaging } \\
\text { modality }\end{array}$ & $\begin{array}{l}\text { Single } \\
\text { modality; } \\
\text { multiple } \\
\text { modality }\end{array}$ & Age & $\begin{array}{l}\text { Modality of } \\
\text { study } \\
\text { acquisition }\end{array}$ & $\begin{array}{l}\text { Publication } \\
\text { Year }\end{array}$ & $\begin{array}{l}\text { No. of yearly } \\
\text { citations }\end{array}$ & $\begin{array}{l}\text { No. of total } \\
\text { citations }\end{array}$ & $\begin{array}{l}\text { Rank of total } \\
\text { citations }\end{array}$ \\
\hline 36 & $\begin{array}{l}\text { An Australian population study of factors } \\
\text { associated with MRI patterns in cerebral } \\
\text { palsy }\end{array}$ & Reid, S. M. & $\begin{array}{l}\text { Developmental } \\
\text { Medicine and } \\
\text { Child Neurology }\end{array}$ & 3.53 & sMRI & Single & $\begin{array}{l}0.08-11 \\
\text { years }\end{array}$ & - & 2014 & 4.4 & 22 & 41 \\
\hline 37 & $\begin{array}{l}\text { MRI and clinical characteristics of } \\
\text { children with hemiplegic cerebral palsy }\end{array}$ & Cioni, G. & Neuropediatrics & 1.65 & sMRI & Single & $1-18.3$ years & - & 1999 & 4.25 & 85 & 12 \\
\hline 38 & $\begin{array}{l}\text { Periventricular leukomalacia: Relationship } \\
\text { between lateral ventricular volume on } \\
\text { brain MR images and severity of cognitive } \\
\text { and motor impairment }\end{array}$ & Melhem, E. R. & Radiology & 7.61 & sMRI & Single & $\begin{array}{l}1.50-12.50 \\
\text { years }\end{array}$ & - & 2000 & 4.21 & 80 & 13 \\
\hline 39 & $\begin{array}{l}\text { Autosomal recessive spastic tetraplegia } \\
\text { caused by AP4M1 and AP4B1 gene } \\
\text { mutation: expansion of the facial and } \\
\text { neuroimaging features }\end{array}$ & Tuysuz, B. & $\begin{array}{l}\text { American journal } \\
\text { of Medical } \\
\text { Genetics Part A }\end{array}$ & 3.26 & sMRI & Single & $\begin{array}{l}2.50-17 \\
\text { years }\end{array}$ & - & 2014 & 4.2 & 21 & 42 \\
\hline 40 & $\begin{array}{l}\text { Correlation between the degree of } \\
\text { periventricular leukomalacia diagnosed } \\
\text { using cranial ultrasound and MRI later in } \\
\text { infancy in children with cerebral-palsy }\end{array}$ & Devries, L. S. & Neuropediatrics & 1.65 & $\begin{array}{l}\text { SMRI and } \\
\text { TCS }\end{array}$ & Multiple & $\begin{array}{l}0.92-2.67 \\
\text { years }\end{array}$ & Sedation & 1993 & 4.19 & 109 & 7 \\
\hline 41 & $\begin{array}{l}\text { Treatment-induced plasticity in cerebral } \\
\text { palsy: a diffusion tensor imaging study }\end{array}$ & Trivedi, R. & $\begin{array}{l}\text { Pediatric } \\
\text { Neurology }\end{array}$ & 2.33 & DTI & Single & $3-12$ years & Sedation & 2008 & 4.09 & 45 & 25 \\
\hline 42 & $\begin{array}{l}\text { Diffusion tensor imaging demonstrates } \\
\text { focal lesions of the corticospinal tract in } \\
\text { hemiparetic patients with cerebral palsy }\end{array}$ & Son, S. M. & $\begin{array}{l}\text { Neuroscience } \\
\text { Letters }\end{array}$ & 2.17 & DTI & Single & $0.90-7$ years & - & 2007 & 3.92 & 47 & 22 \\
\hline 43 & $\begin{array}{l}\text { Diffusion MRI in corticofugal fibers } \\
\text { correlates with hand function in unilateral } \\
\text { cerebral palsy }\end{array}$ & Holmstrom, L. & Neurology & 8.69 & DTI & Single & $\begin{array}{l}7.20-17.30 \\
\text { years }\end{array}$ & - & 2011 & 3.75 & 30 & 32 \\
\hline 43 & $\begin{array}{l}\text { Resting state and diffusion neuroimaging } \\
\text { predictors of clinical improvements } \\
\text { following constraint-induced movement } \\
\text { therapy in children with hemiplegic } \\
\text { cerebral palsy. }\end{array}$ & Manning, K. Y. & $\begin{array}{l}\text { Journal of Child } \\
\text { Neurology }\end{array}$ & 2.09 & DTI and fMRI & Multiple & $6-15$ years & Awake & 2015 & 3.75 & 15 & 44 \\
\hline 45 & $\begin{array}{l}\text { Magnetic-resonance-imaging in children } \\
\text { with spastic diplegia-correlation with } \\
\text { the severity of their motor and mental } \\
\text { abnormality }\end{array}$ & Yokochi, K. & $\begin{array}{l}\text { Developmental } \\
\text { Medicine and } \\
\text { Child Neurology }\end{array}$ & 3.53 & sMRI & Single & $3-10$ years & - & 1991 & 3.71 & 104 & 9 \\
\hline 46 & $\begin{array}{l}\text { Athetotic and spastic cerebral palsy: } \\
\text { Anatomic characterization based on } \\
\text { diffusion-tensor imaging }\end{array}$ & Yoshida, S. & Radiology & 7.61 & DTI & Single & $0.5-15$ years & $\begin{array}{l}\text { Partial } \\
\text { sedation }\end{array}$ & 2011 & 3.5 & 28 & 33 \\
\hline 46 & $\begin{array}{l}\text { Effect of sensory and motor connectivity } \\
\text { on hand function in pediatric hemiplegia }\end{array}$ & Gupta, D. & $\begin{array}{l}\text { Annals of } \\
\text { Neurology }\end{array}$ & 9.5 & $\begin{array}{l}\text { sMRI, DTI, } \\
\text { and TMS }\end{array}$ & Multiple & $\begin{array}{l}7.02-18.12 \\
\text { years }\end{array}$ & - & 2017 & 3.5 & 7 & 49 \\
\hline
\end{tabular}

Neuroscience

Diffusion MRI in corticofugal fibers correlates with hand function in unilatera cerebral palsy predictors of clinical improvements following constraint-induced movement

therapy in children with hemiplegic

cerebral palsy.

with spastic diplegia - correlation with

Medicine and 


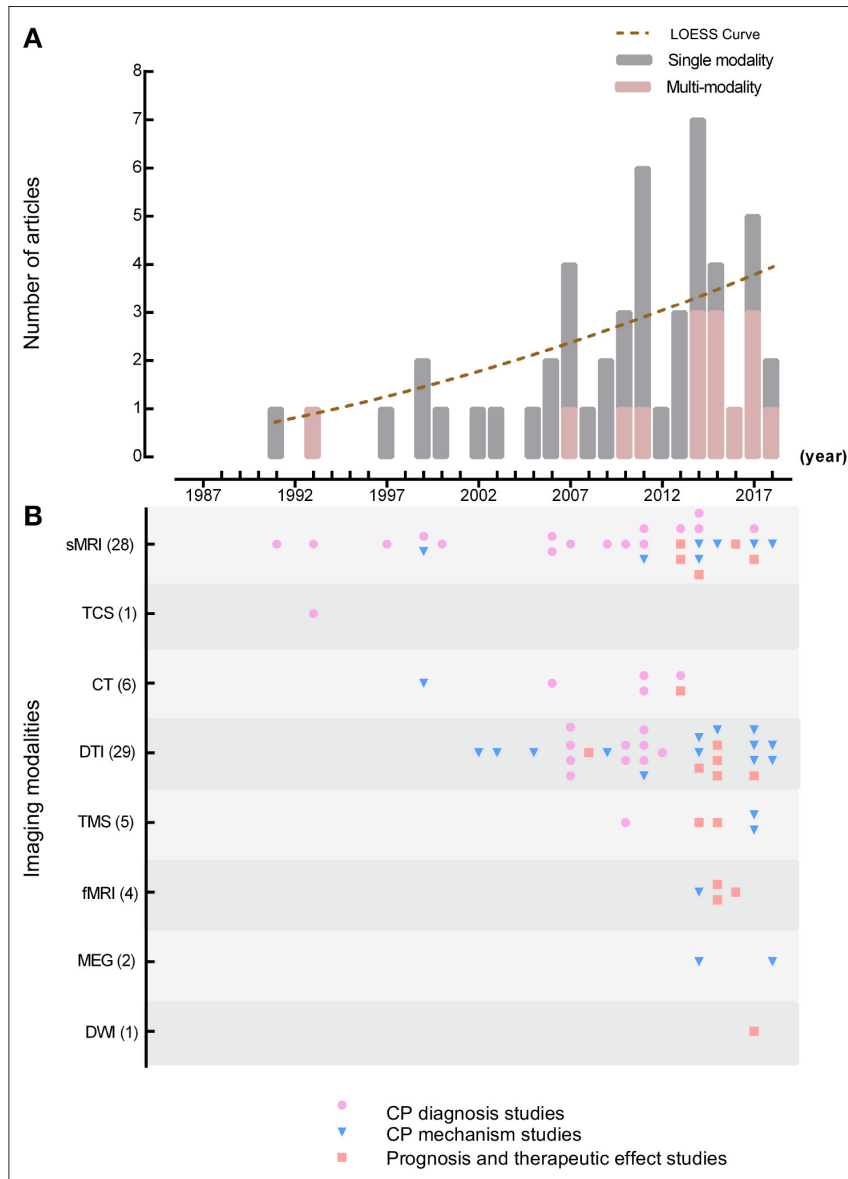

FIGURE 1 | Distribution of imaging modality and study topics. (A) Yearly article counts distribution of the top 50 highly cited original articles utilized single or multiple modality; (B) yearly article counts for each imaging modality used in the top 50 highly cited original articles classified by different research purposes. Different research purposes included CP diagnosis studies, CP mechanism studies, and CP prognosis and therapeutic affect studies. Study purposes are presented in different colors. SMRI, structural magnetic resonance imaging; TCS, transcranial ultrasound; CT, computed tomography; DTI, diffusion tensor imaging; TMS, transcranial magnetic stimulation; fMRI, functional magnetic resonance imaging; MEG, magnetoencephalography; DWI, diffusion-weighted imaging.

function, 1991-2014). For different research purposes, the CP diagnosis studies focused on the correlation between brain image performance and impaired functions (12/25). CP mechanism studies were mostly concerned with the process of hand or upper limb and sensorimotor function (11/15). While therapeutic effect studies used CIMT (5/10), bimanual intensive rehabilitation $(1 / 10)$, autologous cord blood infusion (1/10), and botulinum injection $(1 / 10)$, the assessment of hand or upper limb function $(5 / 10)$ or sensorimotor function $(4 / 10)$ were also involved. However, only one study in development outcome prediction paid attention to hand function in hemiplegia.

\section{Study Designs}

Among the top 50 highly cited articles, $78 \%$ (39/50) were descriptive (19/50,38\%) and cross-sectional studies (20/50, 40\%) 
TABLE 2 | Cerebral palsy types, impaired functions, and study designs of the top 50 highly cited articles in different research purposes.

\begin{tabular}{|c|c|c|c|c|c|c|c|c|c|c|c|c|c|c|}
\hline & & & & \multicolumn{3}{|c|}{ CP diagnosis studies } & \multirow{2}{*}{$\begin{array}{c}\text { CP } \\
\text { mechanism } \\
\text { studies }\end{array}$} & \multicolumn{5}{|c|}{ CP prognosis and therapeutic effect studies } & \multirow{2}{*}{$\begin{array}{l}\text { Published year } \\
\text { (median) }\end{array}$} & \multirow[t]{2}{*}{ Total } \\
\hline & & & & $\begin{array}{l}\text { Diagnostic } \\
\text { value of } \\
\text { imaging } \\
\text { method }\end{array}$ & $\begin{array}{c}\text { Image } \\
\text { performance }\end{array}$ & $\begin{array}{l}\text { Imaging } \\
\text { classification } \\
\text { system and } \\
\text { applications } \\
\text { in CP }\end{array}$ & & $\begin{array}{l}\text { Autologous } \\
\text { cord blood } \\
\text { infusion }\end{array}$ & $\begin{array}{l}\text { Constraint- } \\
\text { induced } \\
\text { movement } \\
\text { therapy }\end{array}$ & $\begin{array}{c}\text { Bimanual } \\
\text { intensive } \\
\text { rehabilitation }\end{array}$ & $\begin{array}{l}\text { Botulinum } \\
\text { injection }\end{array}$ & $\begin{array}{l}\text { Prediction } \\
\text { of function } \\
\text { development }\end{array}$ & & \\
\hline \multirow[t]{7}{*}{ CP types } & Spastic CP & $\begin{array}{l}\text { Single } \\
\text { subtype: }\end{array}$ & Hemiplegia & 1 & 5 & & 10 & & 5 & 1 & & 1 & 1999-2018 (2014) & 23 \\
\hline & & & Diplegia & & $2^{*}$ & & & & & & & & 1991, 2012 & 2 \\
\hline & & & Quadriplegia & & $2^{*}$ & & 2 & & & & 1 & & 2008-2014 (2010) & 5 \\
\hline & & Mixed subtyp & & & 1 & 2 & 1 & 1 & & & & & 2010-2015 (2014) & 5 \\
\hline & & Unclassified s & subtypes & 1 & $2^{\dagger}$ & & & & & & & & 1997-2011 (2000) & 3 \\
\hline & Athetoid CP & & & & $1^{\dagger}$ & & & & & & & & 2011 & 1 \\
\hline & Unclassified & or multiple CP & type mixed & 8 & 1 & 1 & 2 & 1 & & & & & 1993-2017 (2009) & 13 \\
\hline \multirow{4}{*}{$\begin{array}{l}\text { Impaired } \\
\text { functions }\end{array}$} & Sensorimoto & r function & & 1 & $5^{\star} \emptyset$ & & 3 & 1 & $2^{\ddagger}$ & & 1 & & 1991-2017 (2008) & 13 \\
\hline & Specific $m$ & otor function & $\begin{array}{l}\text { Hand or } \\
\text { upper limb } \\
\text { function- } \\
\text { related }\end{array}$ & $1 \#$ & $4^{\dagger}$ & & 8 & & $4^{\ddagger}$ & 1 & & 1 & 1999-2018 (2014) & 19 \\
\hline & & Lower limb fu & unction-related & 1\# & $1^{\dagger}$ & & & & & & & & 1999, 2012 & 2 \\
\hline & Cognitive anc & d function (inclu & uding speech) & 2\# & 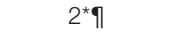 & & & & & & & & 1991-2013 (1999.5) & 4 \\
\hline \multicolumn{4}{|c|}{ Studies not related to impaired function } & 7 & 3 & 3 & 4 & 1 & & & & & 1993-2017 (2010.5) & 18 \\
\hline \multirow[t]{7}{*}{ Study designs } & Descriptive s & tudy & & 10 & 2 & 2 & 5 & & & & & & 1999-2017 (2011) & 19 \\
\hline & Cross-section & nal study & & & 9 & 1 & 10 & & & & & & 2000-2018 (2010.5) & 20 \\
\hline & Case-control & I study & & & 1 & & & & & & & & 2007 & 1 \\
\hline & Cohort study & & & & & & & & & & & 1 & 2013 & 1 \\
\hline & Non-randomi & ized controlled & trial & & & & & & 1 & & & & 2016 & 1 \\
\hline & Paired desigr & ר trial & & & & & & & 4 & 1 & 1 & & 2008-2015 (2014) & 6 \\
\hline & Randomized & controlled trial & & & & & & 2 & & & & & 2015, 2017 & 2 \\
\hline \multirow{2}{*}{\multicolumn{4}{|c|}{ Published year (median) }} & $\begin{array}{c}1993-2014 \\
(2007.5)\end{array}$ & $\begin{array}{c}1991-2012 \\
(2008.5)\end{array}$ & $\begin{array}{c}2011-2017 \\
(2014)\end{array}$ & $\begin{array}{c}1999-2018 \\
(2014)\end{array}$ & 2015, 2017 & $\begin{array}{c}2013-2016 \\
(2014)\end{array}$ & 2015 & 2008 & 2013 & \multirow{2}{*}{\multicolumn{2}{|c|}{ 1991-2018 (2011) }} \\
\hline & & & & & $\begin{array}{c}1991-2017 \\
(2011)\end{array}$ & & & & & $\begin{array}{c}2008-2017 \\
(2014.5)\end{array}$ & & & & \\
\hline \multicolumn{4}{|c|}{ Total articles } & 10 & 12 & 3 & 15 & 2 & 5 & 1 & 1 & 1 & \multicolumn{2}{|l|}{50} \\
\hline
\end{tabular}

The ${ }^{*}, \#,{ }^{\dagger}, \boldsymbol{\eta}$, and $\neq$ symbols signify repeated counting of one article. 
(Table 2). The majority of the CP diagnosis and mechanism studies followed these two study designs. Furthermore, prospective design was adopted in a cohort study of prognosis $(1 / 50,2 \%)$ and in therapeutic effect evaluation studies $(9 / 50$, $18 \%)$. Specifically, therapeutic effect evaluation studies included six paired design trials (12\%), two randomized controlled trials (4\%), and one non-randomized controlled trial (2\%).

Considering that the age range of children at the time of neuroimaging might affect the choice of study design, these subjects were divided into pre- ( $0-3$ years) and post-myelination period ( $>3$ years). Only one study included children at the premyelination period (11-32 months); 23 studies included children at the post-myelination period $(23 / 50,46 \%) ; 23$ studies included children at both the pre- and post-myelination period, while 3 studies did not mention the children's age range.

Thirteen studies mentioned information on the modality of study acquisition (awake, natural sleep, sedation, and general anesthesia). Four studies reported that children were awake during the scanning (one article was published in 2005, ages: 1216 years; three articles were published between 2014 and 2016, ages: 4.75-18 years); two mentioned that children were sedated at the age of 5 years or younger or have difficulty remaining still, while other children over 5 years were screened while awake (published between 2010 and 2011, ages: 0.33-15 years). Seven studies reported that all children included were sedated for the neuroimaging examination (published between 1993 and 2014, ages: $0.92-15$ years), with five of them describing specific sedative drugs and doses in detail. From the above we can tell that only a few articles reported information on the modality of study acquisition. In articles including modality information of the study acquisition, the transition of obtaining images from sedated children to awake children can be observed. Thus, we believe that more attention needs to be paid on the safe acquisition of imaging data of children with CP.

\section{Authors and Publications of the Top 50 Highly Cited Articles \\ First Author Countries}

The country of affiliation of the first author is listed in descending order: USA $(16 / 50,32 \%)$, Sweden $(7 / 50,14 \%)$, Canada $(5 / 50$, $10 \%)$, Italy $(4 / 50,8 \%)$, Australia $(4 / 50,8 \%)$, Japan $(4 / 50,8 \%)$, Belgium (3/50, $6 \%)$, India $(2 / 50,4 \%)$, South Korea $(2 / 50$, $4 \%)$, England $(1 / 50,2 \%)$, Netherlands $(1 / 50,2 \%)$, and Turkey $(1 / 50,2 \%)$.

\section{Journals}

The top 50 highly cited articles were published in 27 journals. The top three journals with the most published articles on pediatric CP were Developmental Medicine and Child Neurology (12 articles, 24\%), NeuroImage: Clinical (4 articles, 8\%), and Pediatrics (3 articles, 6\%). A full list of the article number and most recent journal IFs is shown in Table 3. The journals with the top three IFs in 2018 were JAMA (one article, 2\%), Brain (one article, 2\%), and Annals of Neurology (one article, 2\%).
TABLE 3 | The impact factors and rank of journals which published articles on pediatric cerebral palsy.

\begin{tabular}{|c|c|c|c|}
\hline Journal & $\begin{array}{c}\text { No. of } \\
\text { articles (\%) }\end{array}$ & IF (2018) & Rank* $^{*}$ \\
\hline $\begin{array}{l}\text { Developmental Medicine and } \\
\text { Child Neurology }\end{array}$ & $12(24)$ & 3.53 & 1 \\
\hline Neurolmage: Clinical & $4(8)$ & 3.94 & 2 \\
\hline Pediatrics & $3(6)$ & 5.40 & 3 \\
\hline Neurology & $2(4)$ & 8.69 & 4 \\
\hline Radiology & $2(4)$ & 7.61 & 5 \\
\hline Human Brain Mapping & $2(4)$ & 4.55 & 6 \\
\hline $\begin{array}{l}\text { American Journal of } \\
\text { Neuroradiology }\end{array}$ & $2(4)$ & 3.26 & 7 \\
\hline Neuroscience Letters & $2(4)$ & 2.17 & 8 \\
\hline Journal of Child Neurology & $2(4)$ & 2.09 & 9 \\
\hline Neuropediatrics & $2(4)$ & 1.65 & 10 \\
\hline JAMA & $1(2)$ & 51.27 & 11 \\
\hline Brain & $1(2)$ & 11.81 & 12 \\
\hline Annals of Neurology & $1(2)$ & 9.50 & 13 \\
\hline $\begin{array}{l}\text { STEM CELLS Translational } \\
\text { Medicine }\end{array}$ & $1(2)$ & 5.96 & 14 \\
\hline Neuroimage & $1(2)$ & 5.81 & 15 \\
\hline $\begin{array}{l}\text { Neurorehabilitation and Neural } \\
\text { Repair }\end{array}$ & $1(2)$ & 3.76 & 16 \\
\hline $\begin{array}{l}\text { Journal of Magnetic Resonance } \\
\text { Imaging }\end{array}$ & $1(2)$ & 3.73 & 17 \\
\hline $\begin{array}{l}\text { Frontiers in Human } \\
\text { Neuroscience }\end{array}$ & $1(2)$ & 2.87 & 18 \\
\hline $\begin{array}{l}\text { Archives of Physical Medicine } \\
\text { and Rehabilitation }\end{array}$ & $1(2)$ & 2.70 & 19 \\
\hline Neuroradiology & $1(2)$ & 2.50 & 20 \\
\hline $\begin{array}{l}\text { European Journal of Pediatric } \\
\text { Neurology }\end{array}$ & $1(2)$ & 2.50 & 21 \\
\hline Pediatric Neurology & $1(2)$ & 2.33 & 22 \\
\hline Acta Paediatrica & $1(2)$ & 2.27 & 23 \\
\hline $\begin{array}{l}\text { American Journal of Medical } \\
\text { Genetics Part A }\end{array}$ & $1(2)$ & 2.20 & 24 \\
\hline $\begin{array}{l}\text { Research in Developmental } \\
\text { Disabilities }\end{array}$ & $1(2)$ & 1.87 & 25 \\
\hline Brain \& Development & $1(2)$ & 1.76 & 26 \\
\hline Brain Connectivity & $1(2)$ & - & 27 \\
\hline
\end{tabular}

IF data were collected from Journal Citation Reports for the year 2018. No., number; IF, impact factor; JAMA, Journal of the American Medical Association.

*The journals ranked by number of articles and IF.

\section{DISCUSSION}

Targeting the unclear focus of current studies and future directions in brain imaging for children with $\mathrm{CP}$, our study demonstrated that the main topics of the highly cited articles were the identification and diagnosis of CP (44\%) and understanding its mechanism using MR technologies (30\%), with designs based on low-level evidence. Our results have also indicated that possible future directions in this field could be research on therapy effect evaluation and prognosis using multimodalities, based on high-level evidence design (2008-2017, 
median: 2014.5). Moreover, CP studies on the single subtype SCP and sensorimotor or upper limb-related function have also attracted considerable attention.

This study analyzed the bibliometric information of the top $25 \%$ of articles in order of yearly citation counts in brain imaging for children with CP, since brain imaging has first been applied in CP studies in 1984 (3). According to our research, there is still a lack of agreement on the standard of highly cited articles worldwide. Levitt et al. study mentioned that they chose the top $25 \%$ of yearly citation counts as highly cited articles due to it covering enough articles in the field while still meeting the definition of highly cited articles (12). Therefore, we chose the same standard, namely, the top 25\%. Figure 1 shows that no articles before 1991 were included, although no time limit was set for this study. According to the search results, only three articles were found before 1991, with yearly citation counts between 0.20 and 1.93 , which did not qualify these articles for the top $25 \%$ of the list.

The selection of imaging techniques in $\mathrm{CP}$ studies changed from subjective and descriptive stages to objective and quantitative stages. Before the 21st century, TCS, sMRI, and CT were the first few technologies used in CP studies to help identify brain abnormalities and etiology (13). In the 2000's, with the development of imaging technology, DTI became the most frequently applied method to quantitatively analyze structural changes, mechanisms, and therapy effectiveness in $\mathrm{CP}$ children; it provided objective results for the detection of brain alterations $(14,15)$. From 2010 to 2018, the multi-modality approaches were more frequently used to assess therapy effectiveness and comprehensively discover mechanisms in children with $\mathrm{CP}$ $(16-18)$. This was the result of a high clinical need for the discovery of the relationship between structure and function, in order to improve treatment evaluation $(19,20)$. The practice parameters from the American Academy of Neurology and the Child Neurology Society also recommend the use of MRI over $\mathrm{CT}$ in children with $\mathrm{CP}$, due to its higher rate in identifying etiology and timing (4). Therefore, the application of new MR technologies became mainstream in brain imaging studies of children with $\mathrm{CP}$. The historical trend in brain imaging modalities also reflects the rapid application of the new imaging techniques applied in CP studies. From the identification of lesions to the exploration of fiber pathways and the construction of brain networks, neuroimaging combined with TMS and/or MEG assisting the comprehensive evaluation of etiology, therapy effectiveness, and prognosis with multi-modality has become the route for future studies.

Among the $\mathrm{CP}$ diagnosis studies, the earlier descriptive studies have shown the diagnostic value of imaging examination in identifying the etiology for $\mathrm{CP}$ patients $(21,22)$. Meanwhile, the studies on image performance and features appeared to help understand the causes of $\mathrm{CP}$ and identify the relationship between brain abnormalities and clinical characteristics $(13,23)$. With the development of MR quantitative technology, studies mainly focused on the relevant relationship between structural changes and various functions including sensorimotor function, cognitive (including speech) function, and upper or lower limb function $(14,24)$. Recently, study focus has been shifted from etiology identification to systematically summarizing and classifying the correlation of brain abnormality with possible etiology $(25,26)$. The time of CP diagnosis has also been moved forward to 6 months of corrected age using MRI with a predictive sensitivity of $80-90 \%$ (5). Furthermore, new evidence suggests that $14 \%$ of $\mathrm{CP}$ cases have a genetic component (5). Utilizing molecular genetic techniques combined with neuroimaging to detect specific brain abnormalities has become a new tendency in CP studies (27).

$\mathrm{CP}$ studies have used new imaging techniques and multimodality to explore CP mechanisms $(19,20)$. These studies concentrated mostly on $\mathrm{CP}$ subtypes, particularly hemiplegia, due to its extremely unique pathological mechanism (28). Congenital hemiparesis has become an ideal study model disorder due to its abnormal motor function only present on one side of the body, with the contralateral normal side serving as an internal control (29). Considering the significance of the upper limb and hand function for self-care ability in daily life, most of the studies deeply explored the changes in center-hand pathways and structural neuroplasticity $(19,20)$. Some studies also focused on sensorimotor function-related changes (15). However, very few studies have been found on the mechanism of impaired cognitive functions in children with $\mathrm{CP}$, which needs to be explored in the future. Despite the high incidence of reports on SCP, further investigation is still needed on the mechanisms of other CP subtypes, and an evidence-based study is also essential.

Brain imaging was first implicated in therapeutic evaluation of children with CP in 2008 (30) among 50 highly cited articles. Since then, use of brain imaging to evaluate therapeutic effect in children with $\mathrm{CP}$ has been widely adopted. According to our study, nine articles on the evaluation of therapeutic effect were found after 2008, and seven articles have been published in the last 5 years. The utilization of imaging modality changed from single modality evaluation $(30,31)$ to multi-modality evaluation combined with a functional modality such as TMS (32). The treatments evaluated have also changed from single treatment efficacy evaluation $(30,31)$ to multiple treatment efficacy evaluation, accompanied by the development of possible treatment-specific biomarkers (33). Thus, we can conclude that the use of brain imaging techniques to evaluate therapeutic effect has become the current research focus and can lead the direction of future study.

The continental distribution of the first author includes North America, Europe, Australia, and Asia. The distribution is uneven with a trend toward developed countries. However, in developing countries, more attention is needed in the medical treatments of high-risk $\mathrm{CP}$ populations. Especially due to the financial constraints of low-level economies, the medical and social security systems are underdeveloped, which further affect quality of life of children with CP.

The journals Developmental Medicine and Child Neurology, NeuroImage: Clinical, and Pediatrics featured prominently among the top 50 journals, highlighting their important contribution in shaping the diagnosis, mechanism, and treatment of CP. Several well-known high-IF journals were included in the top 50, for example JAMA, Brain, and Annals of Neurology. It is worth mentioning that JAMA published the 
most cited article in 2006. Although its original publication was 10 years ago, it still maintains the highest number of citations per year. It should also be noted that STEM CELLS Translational Medicine and NeuroImage have published two articles representing randomized clinical trials on autologous cord blood infusion.

\section{Limitations}

There are several limitations to this study. First, we searched the Web of Science All Databases to consider authority and relative comprehensiveness. The literature found in other databases and not included in the Web of Science All Databases was not highly cited. Second, this analysis contained all the original articles. The longer the period since the article was published, the greater the number of citations that can be found, regardless of its impact. To avoid this bias, we used yearly citations to better reflect the impact of the article. Third, the highly cited article only reflects the impact of the articles and the current focus of the field, but not the quality of the study. Thus, to fully evaluate a study field, information such as study design, rigor, or other measures need to be considered. Fourth, the rank of yearly citation counts might be affected by self-citations for some studies. However, the articles ranked after the top 50 most highly cited articles have limited yearly citation counts and do not affect our results. We will also try to avoid the effect of selfcitation in our future studies. Last, the majority of highly cited articles in bibliometric studies are derived from overlapping lists of established journals indexed in major secondary databases. Some studies have reported that recently collected papers should have at least 2 years of historical accumulation of enough citation volume to establish bibliometric reliability (8). Therefore, our study can objectively reflect the hotspots and trends in all related studies up to 2017.

\section{Conclusion}

This study provides an important and comprehensive analyzation of the most cited articles in the field of imaging application in children with $\mathrm{CP}$ over the past 29 years. The

\section{REFERENCES}

1. Graham HK, Rosenbaum P, Paneth N, Dan B, Lin JP, Damiano DL, et al. Cerebral palsy. Nat Rev Dis Primers. (2016) 2:15082. doi: 10.1038/nrdp.2015.82

2. Patel DR, Neelakantan M, Pandher K, Merrick J. Cerebral palsy in children: a clinical overview. Transl Pediatr. (2020) 9:S125-35. doi: 10.21037/tp.2020.01.01

3. Sauerbrei EE. Serial brain sonography in two children with leukomalacia and cerebral palsy. J Can Assoc Radiol. (1984) 35:164-7.

4. Ashwal S, Russman BS, Blasco PA, Miller G, Sandler A, Shevell M, et al. Quality standards subcommittee of the American academy of neurology, practice committee of the child neurology society. Practice parameter: diagnostic assessment of the child with cerebral palsy: report of the quality standards subcommittee of the American academy of neurology and the practice committee of the child neurology society. Neurology. (2004) 62:85163. doi: 10.1212/01.wnl.0000117981.35364.1b

5. Novak I, Morgan C, Adde L, Blackman J, Boyd RN, Brunstrom-Hernandez J, et al. Early, accurate diagnosis and early intervention in cerebral palsy: future direction of this field may lead to multi-modality studies with high-level evidence-based design that investigate the mechanism, prognosis, and therapeutic efficacy of CP. These studies recognized the important study progress in this field and provided a valuable framework and direction toward diagnosis, mechanism, treatment, and prognosis of CP. By offering important insights into the historical trends in this highly active and promising field, these results might have a strong impact on future research.

\section{DATA AVAILABILITY STATEMENT}

All datasets generated for this study are included in the article/supplementary material.

\section{AUTHOR CONTRIBUTIONS}

FW and XW performed the literature search, preliminary article analysis, drafted, and revised the paper. FW, HL, and JZ performed the literature search and screened articles. XW, MW, $\mathrm{CL}, \mathrm{ZZ}$, and $\mathrm{XZ}$ performed the literature search and download. FW, JY, XL, HJ, and TH analyzed the data and revised the draft manuscript. JY and HL oversaw the project and concept design, monitored the data collection, and revised the draft manuscript. All authors contributed substantially to the final article.

\section{FUNDING}

This study was funded by the National Key Research and Development Program of China (2016YFC0100300), the National Natural Science Foundation of China (Nos. 81901732, 81760309, 81901823, 81771810, 81971581, 51706178, $81901516,81471631$, and 81171317$)$, the Innovation Capability Support Program of Shaanxi (2019TD-018), the 2011 New Century Excellent Talent Support Plan of the Ministry of Education, China (NCET-11-0438), and Science and Technology Supporting Program of Guizhou Province (No. qiankehezhicheng [2020]4Y122). advances in diagnosis and treatment. JAMA Pediatr. (2017) 171:897907. doi: 10.1001/jamapediatrics.2017.1689

6. Jiang H, Li X, Jin C, Wang M, Liu C, Chan KC, et al. Early diagnosis of spastic cerebral palsy in infants with periventricular white matter injury using diffusion tensor imaging. AJNR Am J Neuroradiol. (2019) 40:1628. doi: 10.3174/ajnr.A5914

7. Saunders J, Carlson HL, Cortese F, Goodyear BG, Kirton A. Imaging functional motor connectivity in hemiparetic children with perinatal stroke. Hum Brain Mapp. (2019) 40:1632-42. doi: 10.1002/hbm.24474

8. Huang L, Zhang C, Gu J, Wu W, Shen Z, Zhou X, et al. A randomized, placebo-controlled trial of human umbilical cord blood mesenchymal stem cell infusion for children with cerebral palsy. Cell Transplant. (2018) 27:32534. doi: $10.1177 / 0963689717729379$

9. Merigó JM, Yang J-B. A bibliometric analysis of operations research and management science. Omega. (2017) 73(Suppl. c):37-48. doi: 10.1016/j.omega.2016.12.004

10. Kim HJ, Yoon DY, Kim ES, Lee K, Bae JS, Lee JH. The 100 mostcited articles in neuroimaging: a bibliometric analysis. NeuroImage. (2016) 139:149-56. doi: 10.1016/j.neuroimage.2016.06.029 
11. Nyanchoka L, Tudur-Smith C, Thu VN, Iversen V, Tricco AC, Porcher R. A scoping review describes methods used to identify, prioritize and display gaps in health research. J Clin Epidemiol. (2019) 109:99110. doi: 10.1016/j.jclinepi.2019.01.005

12. Levitt JM, Thelwall M. Does the higher citation of collaborative research differ from region to region? A case study of economics. Scientometrics. (2010) 85:171-83. doi: 10.1007/s11192-010-0197-5

13. Okumura A, Hayakawa F, Kato T, Kuno K, Watanabe K. MRI findings in patients with spastic cerebral palsy. I: correlation with gestational age at birth. Dev Med Child Neurol. (1997) 39:363-8. doi: 10.1111/j.1469-8749.1997.tb07447.x

14. Bleyenheuft Y, Grandin CB, Cosnard G, Olivier E, Thonnard JL. Corticospinal dysgenesis and upper-limb deficits in congenital hemiplegia: a diffusion tensor imaging study. Pediatrics. (2007) 120:e1502-11. doi: 10.1542/peds.2007-0394

15. Hoon AH Jr, Stashinko EE, Nagae LM, Lin DD, Keller J, Bastian A, et al. Sensory and motor deficits in children with cerebral palsy born preterm correlate with diffusion tensor imaging abnormalities in thalamocortical pathways. Dev Med Child Neurol. (2009) 51:697704. doi: 10.1111/j.1469-8749.2009.03306.x

16. Sun JM, Song AW, Case LE, Mikati MA, Gustafson KE, Simmons R, et al. Effect of autologous cord blood infusion on motor function and brain connectivity in young children with cerebral palsy: a randomized, placebo-controlled trial. Stem Cells Transl Med. (2017) 6:2071-8. doi: 10.1002/sctm.17-0102

17. Islam M, Nordstrand L, Holmström L, Kits A, Forssberg H, Eliasson AC. Is outcome of constraint-induced movement therapy in unilateral cerebral palsy dependent on corticomotor projection pattern and brain lesion characteristics? Dev Med Child Neurol. (2014) 56:252-8. doi: $10.1111 /$ dmcn. 12353

18. Manning KY, Menon RS, Gorter JW, Mesterman R, Campbell C, Switzer L, et al. Neuroplastic sensorimotor resting state network reorganization in children with hemiplegic cerebral palsy treated with constraint-induced movement therapy. J Child Neurol. (2016) 31:220-6. doi: 10.1177/0883073815588995

19. Papadelis C, Ahtam B, Nazarova M, Nimec D, Snyder B, Grant PE, et al. Cortical somatosensory reorganization in children with spastic cerebral palsy: a multimodal neuroimaging study. Front Hum Neurosci. (2014) 8:725. doi: 10.3389/fnhum.2014.00725

20. Rose S, Guzzetta A, Pannek K, Boyd R. MRI structural connectivity, disruption of primary sensorimotor pathways, and hand function in cerebral palsy. Brain Connect. (2011) 1:309-16. doi: 10.1089/brain.2011.0034

21. Bax M, Tydeman C, Flodmark O. Clinical and MRI correlates of cerebral palsy: the European cerebral palsy study. JAMA. (2006) 296:1602-8. doi: 10.1001/jama.296. 13.1602

22. Cioni G, Sales B, Paolicelli PB, Petacchi E, Scusa MF, Canapicchi R. MRI and clinical characteristics of children with hemiplegic cerebral palsy. Neuropediatrics. (1999) 30:249-55. doi: 10.1055/s-2007973499

23. Himmelmann K, Uvebrant P. Function and neuroimaging in cerebral palsy: a population-based study. Dev Med Child Neurol. (2011) 53:51621. doi: 10.1111/j.1469-8749.2011.03932.x
24. Holmström L, Vollmer B, Tedroff K, Islam M, Persson JK, Kits A, et al. Hand function in relation to brain lesions and corticomotor-projection pattern in children with unilateral cerebral palsy. Dev Med Child Neurol. (2010) 52:145-52. doi: 10.1111/j.1469-8749.2009.03496.x

25. Himmelmann K, Horber V, De La Cruz J, Horridge K, Mejaski-Bosnjak V, Hollody K, et al. MRI classification system (MRICS) for children with cerebral palsy: development, reliability, and recommendations. Dev Med Child Neurol. (2017) 59:57-64. doi: 10.1111/dmcn.13166

26. Fiori S, Cioni G, Klingels K, Ortibus E, Van Gestel L, Rose S, et al. Reliability of a novel, semi-quantitative scale for classification of structural brain magnetic resonance imaging in children with cerebral palsy. Dev Med Child Neurol. (2014) 56:839-45. doi: 10.1111/dmcn.12457

27. Tüysüz B, Bilguvar K, Koçer N, Yalçinkaya C, Çaglayan O, Gül E, Sahin S, et al. Autosomal recessive spastic tetraplegia caused by AP4M1 and AP4B1 gene mutation: expansion of the facial and neuroimaging features. Am J Med Genet A. (2014) 164A:1677-85. doi: 10.1002/ajmg.a.36514

28. Jaspers E, Byblow WD, Feys H, Wenderoth N. The corticospinal tract: a biomarker to categorize upper limb functional potential in unilateral cerebral palsy. Front Pediatr. (2015) 3:112. doi: 10.3389/fped.2015.00112

29. Glenn OA, Henry RG, Berman JI, Chang PC, Miller SP, Vigneron DB, et al. DTI-based three-dimensional tractography detects differences in the pyramidal tracts of infants and children with congenital hemiparesis. J Magn Reson Imaging. (2003) 18:641-8. doi: 10.1002/jmri.10420

30. Trivedi R, Gupta RK, Shah V, Tripathi M, Rathore RK, Kumar $\mathrm{M}$, et al. Treatment-induced plasticity in cerebral palsy: A diffusion tensor imaging study. Pediatr Neurol. (2008) 39:34149. doi: 10.1016/j.pediatrneurol.2008.07.012

31. Englander ZA, Sun J, Laura Case L, Mikati MA, Kurtzberg J, Song AW. Brain structural connectivity increases concurrent with functional improvement: evidence from diffusion tensor MRI in children with cerebral palsy during therapy. NeuroImage Clin. (2015) 7:315-24. doi: 10.1016/j.nicl.2015.01.002

32. Bleyenheuft Y, Dricot L, Gilis N, Kuo HC, Grandin C, Bleyenheuft $\mathrm{C}$, et al. Capturing neuroplastic changes after bimanual intensive rehabilitation in children with unilateral spastic cerebral palsy: a combined DTI, TMS and fMRI pilot study. Res Dev Disabil. (2015) 43-4:136-49. doi: 10.1016/j.ridd.2015.06.014

33. Simon-Martinez C, Mailleux L, Ortibus E, Fehrenbach A, Sgandurra G, Cioni $\mathrm{G}$, et al. Combining constraint-induced movement therapy and actionobservation training in children with unilateral cerebral palsy: a randomized controlled trial. BMC Pediatr. (2018) 18:250. doi: 10.1186/s12887-018-1228-2

Conflict of Interest: The authors declare that the research was conducted in the absence of any commercial or financial relationships that could be construed as a potential conflict of interest.

Copyright (C) $2020 \mathrm{Wu}$, Wang, Li, Jiang, Huang, Liu, Wang, Zhai, Zhang, Zhang, Liu and Yang. This is an open-access article distributed under the terms of the Creative Commons Attribution License (CC BY). The use, distribution or reproduction in other forums is permitted, provided the original author(s) and the copyright owner(s) are credited and that the original publication in this journal is cited, in accordance with accepted academic practice. No use, distribution or reproduction is permitted which does not comply with these terms. 